\title{
NOTE
}

\section{Thermophilic bacterial activity in a deep-sea sediment from the Pacific Ocean}

\author{
Fred C. Dobbs ${ }^{1, *}$, Karen A. Selph ${ }^{2}$ \\ ${ }^{1}$ Department of Oceanography, Old Dominion University, 1054 West 47 th Street, Norfolk, Virginia 23529-0276, USA \\ ${ }^{2}$ Department of Oceanography, University of Hawaii, 1000 Pope Road, Honolulu, Hawaii 96822, USA
}

\begin{abstract}
Thermophilic bacterial activity was detected in a deep-sea sediment sample from the South Pacific Ocean at $12^{\circ} \mathrm{S}, 135^{\circ} \mathrm{W}$, an area of the seafloor distant from known hydrothermal venting. Incubation of sediments amended with ${ }^{14} \mathrm{C}$-glutamate indicated maximal respiration (evolution of ${ }^{14} \mathrm{CO}_{2}$ ) and assimilation (incorporation of ${ }^{14} \mathrm{C}$ into acid-precipitated macromolecules) of substrate at $52^{\circ} \mathrm{C}$, relative to 4 and $22^{\circ} \mathrm{C}$. A parallel experiment at another site $\left(2^{\circ} \mathrm{S}, 140^{\circ} \mathrm{W}\right)$ yielded no evidence of thermophily. Thermophilic bacteria may be deposited in deep-sea sediments following their longdistance dispersal from hydrothermal vents (e.g. the East Pacific Rise and other sites), via either continuous venting or formation of megaplumes.
\end{abstract}

KEY WORDS: Deep sea - Thermophilic bacteria - Hydrothermal venting $\cdot$ Dispersal

Most of the ocean's sedimentary environment is cold, given that deep-water $(>1000 \mathrm{~m}$ ) temperatures typically range between 0 and $4^{\circ} \mathrm{C}$ (Knauss 1978). Indigenous deep-sea bacteria, therefore, generally are considered adapted to grow at low temperatures ('psychrophilic') (e.g. Zobell \& Morita 1959, Jannasch \& Taylor 1984). Nonetheless, thermophilic bacteria have been isolated from deep-sea sediment (Bartholomew \& Rittenberg 1949, Bartholomew \& Paik 1966). The presence of these so-called 'alien bacteria' (Bartholomew \& Paik 1966) was enigmatic prior to the discovery in the late 1970 s of hydrothermal vents along the mid-ocean ridge. Indeed, both aerobic (Marteinsson et al. 1995) and anaerobic (e.g. Huber et al. 1989) thermophilic bacteria have been isolated from deepsea hydrothermal vents. Furthermore, thermophilic bacterial activity has been reported in water emanating from deep-sea hydrothermal plumes (review in Karl 1995). There have been no published accounts, however, of thermophilic activity in deep-sea sediments distant from hydrothermal vents. This note is the

·E-mail: dobbs@ocean.odu.edu first report of such activity and suggests hydrothermal venting and deep-water circulation may facilitate long-distance transport of thermophiles.

Samples were collected during Cruise TT013 (October to December 1992) of the Joint Global Ocean Flux Study in the Equatorial Pacific. Because of time and material constraints, tests for thermophily were conducted only at Stn $10\left(12.00^{\circ} \mathrm{S}, 134.95^{\circ} \mathrm{W}\right.$, depth $=$ $4280 \mathrm{~m})$ and $\operatorname{Stn} 23\left(1.87^{\circ} \mathrm{S}, 139.80^{\circ} \mathrm{W}\right.$, depth $=$ $4380 \mathrm{~m}$ ). These stations are located on flat, sedimentcovered abyssal plains, many hundreds of $\mathrm{km}$ distant from any known hydrothermal activity. Virtually undisturbed samples of sediment were collected using a multicorer (Barnett et al. 1984). Within 5 min of the multicorer's arrival on deck, the tube containing sediment for analysis was transferred to a cold room. Overlying water was carefully siphoned off, the sediment was extruded, and samples were taken to determine carbon turnover at simulated deep-sea temperature and pressure (Dobbs \& Selph unpubl.). As a very modest compliment to this primary study, sediment from the uppermost horizon ( 0 to $5 \mathrm{~mm}$ ) was examined for thermophilic activity

Microbial utilization of carbon was evaluated using the method developed by Deming (1993). Sediment was homogenized in a sterile Petri dish, then diluted 12 -fold with filtered $(0.2 \mu \mathrm{m})$ seawater. Four $\mathrm{ml}$ of the slurry were drawn into a plastic $5 \mathrm{ml}$ syringe already containing $1.0 \mathrm{ml}$ of radiolabeled glutamic acid in a solution of filter-sterilized seawater (Amersham, L-[U${ }^{14} \mathrm{C}$ /glutamic acid, specific activity $266 \mathrm{mCi} \mathrm{mmol}^{-1}$; final concentration $\leq 1.5 \mathrm{ng} \mathrm{ml}^{-1}$ ). A sterile needle was affixed to the Luer end of the syringe and inserted into a small piece of rubber. Groups of syringes were placed into plastic bags, which then were sealed and incubated in water baths for $24 \mathrm{~h}$ at 4,22 , or $52^{\circ} \mathrm{C}$. The warmest treatment was achieved by adding hot water every $2 \mathrm{~h}$ to an insulated container; therefore, 
temperature varied over time (mean of $52^{\circ} \mathrm{C}$, range over $2 \mathrm{~h}$ was 47 to $57^{\circ} \mathrm{C}$ ). Temperature was held nearly constant $\left( \pm 1^{\circ} \mathrm{C}\right)$ at the 2 lower temperatures. Samples were mixed by shaking them every $2 \mathrm{~h}$. Poisoned sediments (formalin, final concentration $8 \mathrm{ml} \mathrm{ml}^{-1}$ ) served as controls for abiotic uptake of radioactivity. All treatments and controls were prepared in duplicate.

To terminate the incubations, the sediment slurries in the syringes were injected into serum bottles containing acid $(1.0 \mathrm{M} \mathrm{HCl}) .{ }^{14} \mathrm{CO}_{2}$ was collected on strips of paper containing phenethylamine and radioassayed (Hobbie \& Crawford 1969, Iverson et al. 1976) using Optima Gold (Packard) as the liquid scintillation fluor. Macromolecules were precipitated with cold trichloroacetic acid ( $10 \%$ final concentration, w/v), collected on $\mathrm{GF} / \mathrm{F}$ filters, and radioassayed as above. Background counts were subtracted from sample counts before counts per minute (CPM) were converted to disintegrations per minute (DPM) using the external-standards channels ratio. Samples were counted for $20 \mathrm{~min}$ or until counting error was $\leq 2 \%$. Results of the ${ }^{14} \mathrm{CO}_{2}$ assay represent respiration, those of the ${ }^{14} \mathrm{C}$-macromolecule assay, assimilation. Within-station comparisons were made to test treatment effects (Deming 1993).

A thermophilic response to the provision of ${ }^{14} \mathrm{C}$-glutamic acid was evident at $\operatorname{Stn} 10$, where bacterial respiration was 3.6 and 13.2 times greater at $52^{\circ} \mathrm{C}$ than at 4 and $22^{\circ} \mathrm{C}$, respectively (Fig. 1A). A very similar pattern emerged with respect to assimilation; values at $52^{\circ} \mathrm{C}$ were 2.1 and 9.9 times greater than at 4 and $22^{\circ} \mathrm{C}$, respectively. On the other hand, a thermophilic response was not detected at Stn 23, where respiration and assimilation were 17 to 52 times greater at 4 and $23^{\circ} \mathrm{C}$ than at $52^{\circ} \mathrm{C}$ (Fig. $1 \mathrm{~B}$ ). Values for assimilation controls at Stn 10 were slightly more than twice those at Stn 23, presumably related to the $>2$-fold difference in ${ }^{14} \mathrm{C}$-glutamate concentrations used. We cannot account, however, for the incongruous respiration controls at Stn 10, but note the values were independent of temperature.

Because the intent of these experiments merely was to test for a thermophilic 'treatment effect' (Deming 1993), we did not incorporate into this analysis interstation differences in glutamate specific activity, bacterial numbers, or bulk sediment properties. Furthermore, our experimental design precluded determination of a barophilic response, although there exists a significant barophilic component in deep-sea, sedimentary bacterial communities (e.g. Zobell \& Morita 1959, Jannasch \& Taylor 1984, Deming \& Colwell 1985). Finaily, a 24 h incubation could measure metabolic activity only of bacteria already active or those reactivated by sample processing.

The thermophilic organisms in these experiments were heterotrophic, or at least facultatively so; inherent in the assay is their ability to metabolize glutamate. Also, they functioned in the presence of oxygen; no precautions were taken to limit gas diffusion or to provide reducing conditions. Furthermore, they were not obligate barophiles; all incubations were conducted at 1 atmosphere pressure. As to their degree of thermophily, this study's highest temperature treatment $\left(52^{\circ} \mathrm{C}\right)$ approximated the threshold at which prokaryotic thermophily is considered to begin, i.e. 55 to $60^{\circ} \mathrm{C}$ (Brock 1985) and $60^{\circ} \mathrm{C}$ (Baross \& Deming 1995). Thus, although the bacterial activity reported here arguably is thermophilic, it is at the lower end of the operational definition.

There is no evidence the thermophilic effect at Stn 10 was produced by a eurythermal population(s) of
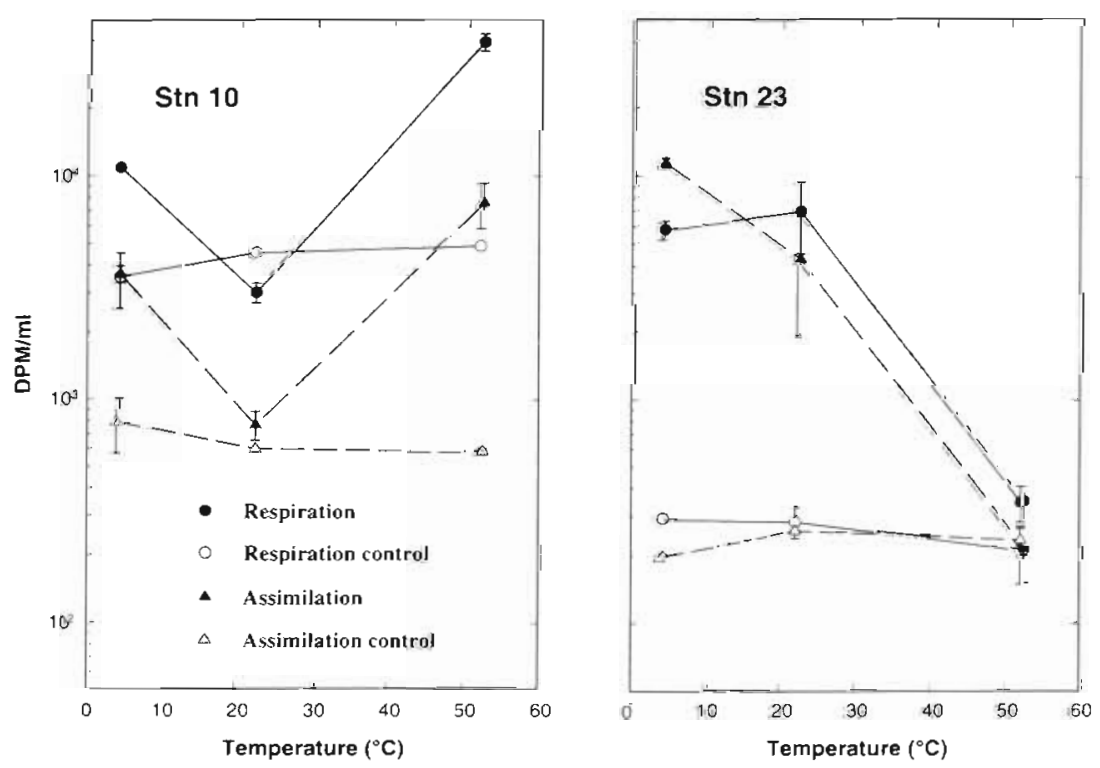

Fig. 1 Respiration and assimilation of ${ }^{14} \mathrm{C}$-glutamate in deep-sea sediments. (A) Stn $10\left(12.00^{\circ} \mathrm{S}, 134.95^{\circ} \mathrm{W}\right)$ depth $=$ $4280 \mathrm{~m}_{i}$ (B) $\operatorname{Stn} 23\left(1.87^{\circ} \mathrm{S}, 139.80^{\circ} \mathrm{W}\right)$ depth $=4380 \mathrm{~m}$. Data are $\log _{10}$ disintegrations $\mathrm{min}^{-1}$ (DPM) per $\mathrm{ml}$ of sediment (Stn 10: $1 \mathrm{ml}$ sediment $=0.279 \pm 0.019 \mathrm{~g}$ dry mass; $\operatorname{Stn} 23: 1 \mathrm{ml}$ sediment $=0.345 \pm$ $0.016 \mathrm{~g}$ dry mass; mean $\pm 1 \mathrm{SD}, \mathrm{n}=4$ ). Plotted values represent mean DPM ml-1 $\pm 1 \mathrm{SD}(n=2)$. When not visible, the standard deviation is less than the size of the symbol. The specific activity of ${ }^{14} \mathrm{C}$-glutamate used at Stn 10 was $5.8 \times 10^{3}$ DPM $\mathrm{ml}^{-1}$, equivalent to a glutamate concentration of $1.5 \mathrm{ng} \mathrm{ml}^{-1}$; corresponding values at $\operatorname{Stn} 23$ were $2.4 \times 10^{3} \mathrm{DPM} \mathrm{ml}^{-1}$ and $0.6 \mathrm{ng} \mathrm{mI^{-1 }}$ Control values represent samples poisoned with formalin 
bacteria. Respiration and assimilation were greater at 4 and $52^{\circ} \mathrm{C}$ than at $22^{\circ} \mathrm{C}$, suggesting psychrophilic and thermophilic populations were more metabolically active than mesophilic bacteria, at least with respect to glutamate as a substrate.

These experiments were not designed to detect extreme thermophiles, also called hyperthermophiles (e.g. Baross \& Deming 1995). This group of organisms, with optimal growth temperatures of $80^{\circ} \mathrm{C}$ or higher, probably contributed little, if anything, to these results. Nearly all marine hyperthermophiles are strict anaerobes (Baross \& Deming 1995), and although they can survive for years in the laboratory in the presence of oxygen if kept cold (Stetter 1995), they would not have been metabolically active under the conditions described here.

Given ca $450 \mathrm{~km}$ distance to the nearest inhabited island, it is most unlikely that terrestrial sources of thermophilic cells figured significantly in these results. While the possibility exists that overboard disposal from ships may contribute minimally to thermophiles in deepsea sediments, a more intuitive source of such bacteria is the vast expanse of hydrothermal vents associated with the mid-ocean ridge, ridge flanks, and geophysical 'hot spots' in the Pacific Ocean. The flux of dissolved and particulate materials from these vents imparts on the emanating water not only a distinctive chemical signature, but in many systems enriches its microbial components as well (review in Winn et al. 1995). In addition to continuous but variable steady-state venting, socalled 'megaplumes' are formed through rapid and massive injection of hydrothermal fluids (and their microbial constituents) into the overlying water column (Baker et al. 1987, Cann \& Strens 1987).

Whatever the method of venting, the warm water so released rises quickly and forms a neutrally buoyant plume detectable hundreds, even thousands, of kilometers downstream (e.g. Lupton \& Craig 1981). Bacterial numbers and biomass are elevated in hydrothermal plumes, due in part to growth of cells utilizing the plumes' organic and inorganic energy sources (Winn et al. 1995). Particle-associated cells not digested by predators or lysed by viruses eventually will fall to the sediments. Dymond \& Roth (1988) estimated the residence time for particles in a plume to be on the order of $100 \mathrm{~d}$. It seems reasonable, then, to hypothesize a diminishing community of hydrothermal-vent bacteria in deep-sea sediments downstream of vents, analogous to the trail of microbial and geochemical signatures in the water column (e.g. Lupton \& Craig 1981, Winn et al. 1995).

Therefore, we suggest plume-transported and plumegenerated microbial biomass was the source material for the thermophilic activity detected at Stn 10. While the precise point of origin cannot be known, inspection of general circulation patterns do not rule out considering the East Pacific Rise (EPR), more than $2000 \mathrm{~km}$ to the east. We note the plume of the EPR's ${ }^{3} \mathrm{He}$-anomaly extends directly over Stn 10 and is discernible to the west for hundreds more km (Lupton \& Craig 1981, Urabe et al. 1995). However, given the relative proximity of many recently discovered mid-plate hot spots in the South Pacific (Fornari et al. 1987), closer hydrothermal systems are more plausible sources.

If the dispersal of plumes and megaplumes is indeed so extensive, then why was there no evidence of thermophily at Stn 23? The answer is suggested by comparison of sediment characteristics at the 2 sites. Sediments at Stn 10 are between 20 and $40 \%$ hydrothermal in origin and composed principally of nonbiogenic particles, whereas those at Stn 23 are predominantly (80\%) biogenic particles of calcium carbonate (Leinen $\&$ Stakes 1979). If thermophiles are attached to hydrothermal particles, then they would be more abundant at Stn 10. Furthermore, particle-deposition rates at Stn 23 are more than 3 times greater than at Stn 10 (Honjo et al. 1995), consistent with relatively high levels of circum-equatorial primary productivity. Therefore, any thermophiles deposited at the sedimentwater interface near the equator would be 'diluted' relative to their concentration at Stn 10 .

Long-distance advective dispersal of hydrothermal microorganisms may account in part for the presence of certain Archaea in the water column. For example, Huber et al. (1990) reported a minimum hyperthermophile concentration of $10^{6} \mathrm{I}^{-1}$ within the hydrothermal plume of Macdonald Seamount, which erupted only $40 \mathrm{~m}$ below the ocean's surface. It seems improbable, however, that thermophilic Archaea are active members of the bacterioplankton community, as suggested for other Archaea detected in the water column (DeLong 1992, Massana et al. 1997). Instead, thermophiles likely are metabolically dormant (or dying) and merely in transit following their discharge from a hydrothermal vent.

Acknowledgements. We thank Anne Slaughter for technical assistance, Craig Smith and his personnel for collecting multicorer samples, Chief Scientist Margaret Leinen, and the Master, Chief Engineer, and crew of the RV 'Thomas G. Thompson'. We appreciate discussions with John Baross, James Cowen, Jody Deming, Peter Sedwick, and Patricia Yager as well as comments on earlier versions of this manuscript by David Burdige, Keun-hyung Choi, Lisa Drake, Craig Moyer, and reviewers. This research was supported by NSF Grant OCE-9022408 (to F.C.D.) and is JGOFS Contribution no. 374.

\section{LITERATURE CITED}

Baker ET, Massoth GH, Feely RA (1987) Cataclysmic hydrothermal venting on the Juan de Fuca Ridge. Nature (Lond) 329:149-151 
Barnett PRO, Watson J, Connelly D (1984) A multiple corer for taking virtually undisturbed samples from shelf, bathyal and abyssal sediments. Oceanol Acta 7:399-408

Baross JA, Deming JW (1995) Growth at high temperatures: isolation and taxonomy, physiology, and ecology. In: Karl DM (ed) The microbiology of deep-sea hydrothermal vents. CRC Press, Boca Raton, p 169-217

Bartholomew JW, Paik G (1966) Isolation and identification of obligate thermophilic sporeforming bacilli from ocean basin cores. J Bacteriol 92:635-638

Bartholomew JW, Rittenberg SC (1949) Thermophilic bacteria from deep ocean bottom cores. J Bacteriol 57:658

Brock TD (1985) Life at high temperatures. Science 230: $132-138$

Cann J, Strens R (1987) Venting events in hot water. Nature (Lond) 329:104

DeLong EF (1992) Archaea in coastal marine environments. Proc Natl Acad Sci USA 89:5685-5689

Deming $J W$ (1993) " $\mathrm{C}$ iracer method for measuring microbial activity in deep-sea sediments. In: Kemp PF, Sherr BF, Sherr EB, Cole JJ (eds) Handbook of methods in aquatic microbial ecology. Lewis Publishers, Boca Raton, p 405-414

Deming JW, Colwell RR (1985) Observations of barophilic microbial activity in samples of sediment and intercepted particulates from the Demerara abyssal plain. Appl Environ Microbiol 50:1002-1006

Dymond J, Roth S (1988) Plume dispersed hydrothermal particles: a time-series record of settling flux from the Endeavor Ridge using moored sediment traps. Geochim Cosmochim Acta 52:2525-2536

Fornari DJ, Batiza R, Luckman MA (1987) Seamount abundances and distribution near the East Pacific Rise $0^{\circ}-24^{\circ}$ $N$ based on Seabeam data. Am Geophys Monogr 43:13-21

Hobbie JE, Crawford CC (1969) Respiration corrections for bacterial uptake of dissolved organic compounds in natural waters. Limnol Oceanogr 14:528-532

Honjo S, Dymond J, Collier R, Manganini SJ (1995) Export production of particles to the interior of the equatorial Pacific Ocean during the 1992 EqPac experiment. Deep Sea Res II 42:831-870

Huber R, Kurr M, Jannasch HW, Stetter KO (1989) A novel group of abyssal methanogenic archaebacteria (Me-

Responsible Subject Editor: Henry Blackburn, Aarhus, Denmark thanopyrus) growing at $110^{\circ} \mathrm{C}$. Nature (London) 342 $833-834$

Huber R, Stoffers P, Cheminee JL, Richnow HH, Stetter KO (1990) Hyperthermophilic archaebacteria within the crater and open-sea plume of erupting Macdonald Seamount. Nature (Lond) 345:179-182

Iverson RL, Bittaker HF, Myers VB (1976) Loss of radiocarbon in direct use of Aquasol for liquid scintillation counting of solutions containing ${ }^{14} \mathrm{C}-\mathrm{NaHCO}_{3}$. Limnol Oceanogr 21: $756-758$

Jannasch HW, Taylor CD (1984) Deep-sea microbiology. Annu Rev Microbiol 38:487-514

Karl DM (1995) Ecology of free-living, hydrothermal vent microbial communities. In: Karl DM (ed) The microbiology of deep-sea hydrothermal vents. CRC Press, Boca Raton, p 35-124

Knauss JA (1978) Introduction to physical oceanography. Prentice-Hall Inc, Englewood Cliffs, NJ

Leinen $M$ Stakes D (1979) Metal acrumulation rates in the central equatorial Pacific during Cenozoic time. Geol Soc Am Bull I 90:357-375

Lupton JE, Craig H (1981) A major helium-3 source at $15^{\circ} \mathrm{S}$ on the East Pacific Rise. Science 214:13-18

Marteinsson VT, Birrien JL, Kristjánsson JK, Prieur D (1995) First isolation of thermophilic aerobic non-sporulating heterotrophic bacteria from deep-sea hydrothermal vents. FEMS Microbiol Ecol 18:163-174

Massana R, Murray AE, Preston CM, DeLong EF (1997) Vertical distribution and phylogenetic characterization of marine planktonic Archaea in the Santa Barbara Channel. Appl Environ Microbiol 63:50-56

Stetter KO (1995) Microbial life in hyperthermal environments. Am Soc Microbiol News 61:285-290

Urabe $T$ and 29 others (1995) The effect of magmatic activity on hydrothermal venting along the superfast-spreading East Pacific Rise. Science 269:1092-1095

Winn CD, Cowen JP, Karl DM (1995) Microbes in deep-sea hydrothermal plumes. In: Karl DM (ed) The microbiology of deep-sea hydrothermal vents. CRC Press, Boca Raton, p 255-273

Zobell CE, Morita RY (1959) Deep-sea bacteria. Galathea Rep Copenhagen 1:139-154

Manuscript received: October 28, 1996

Revised version accepted: March 19, 1997 